Images in...

\title{
Incidental finding of an anterior sub-hepatic appendix during laparoscopic cholecystectomy
}

Siddek Isreb, ${ }^{1}$ Stephen Holtham, ${ }^{2}$

${ }^{1}$ Department of General Surgery, North Tyneside General Hospital, Northumbria Health Care NHS Trust, Newcastle Upon Tyne, UK

${ }^{2}$ Department of Surgery, City Hospital Sunderland NHS Trust, Tyne \& Wear, UK

Correspondence to Siddek Isreb, drisreb@yahoo.com

\section{DESCRIPTION}

Young women with no past surgical history presented with recurrent biliary colic. Abdominal ultrasound scan confirmed gallstones and she was listed for laparoscopic cholecystectomy. An incidental finding of an anterior sub-hepatic normal appendix was made during the operation. We are not aware of any previous normal sub-hepatic appendix images in the literature.
The presence of a sub-hepatic appendix is rare and usually retrocaecal. Palanivelu et $a l^{1}$ reported an incidence of $0.08 \%$ sub-hepatic appendix in 7210 appendicitis in India. Sub-hepatic appendicitis cases are usually missed preoperatively and only diagnosed at laparoscopy. Sub-hepatic appendicular abscess is the most reported presentation. Sub-hepatic appendicitis could easily mimic acute cholecystitis symptoms ${ }^{2}$ and the presence of fecalith could be mistaken for gallstones in an ultrasound scan examination.

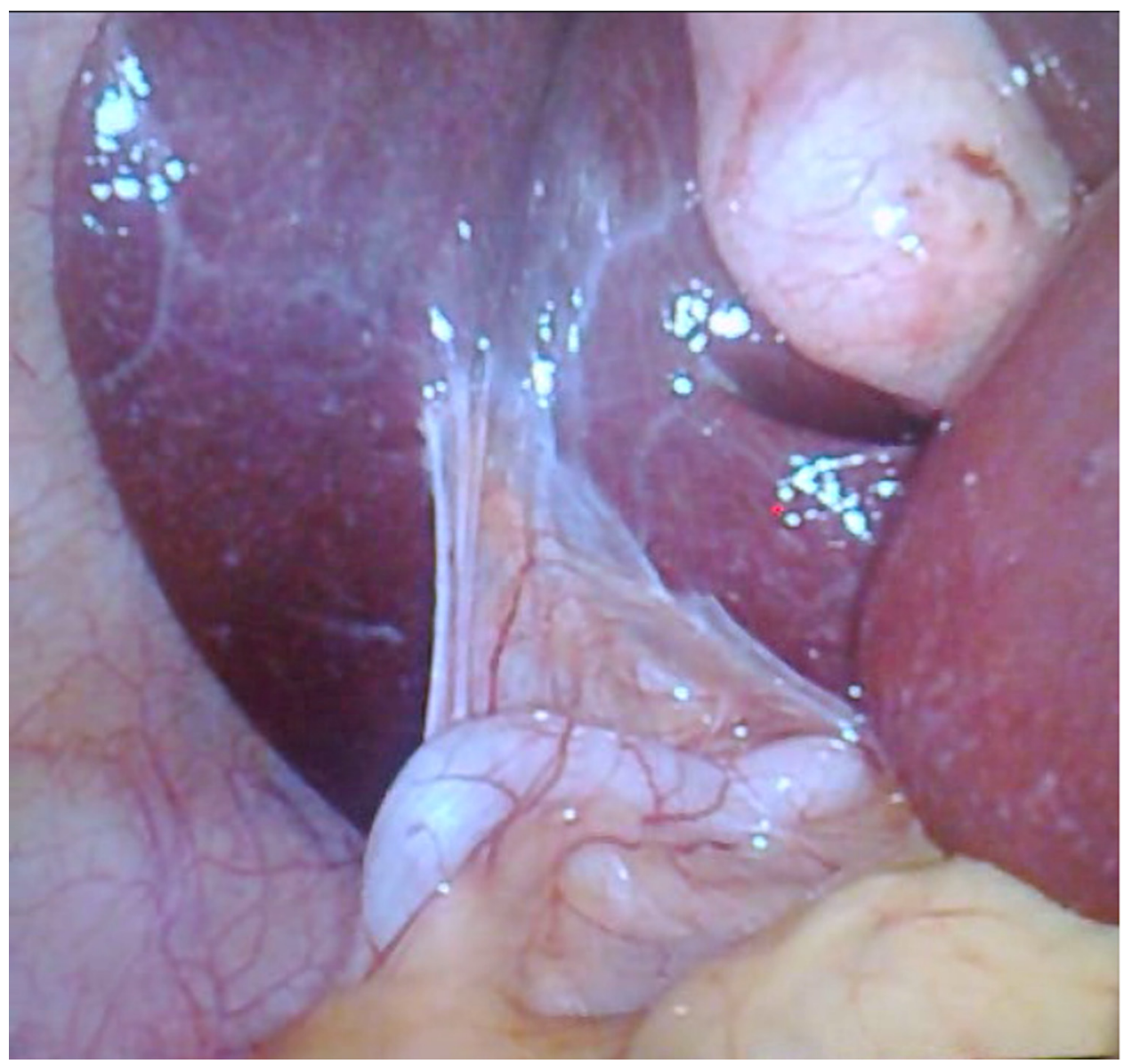

Figure 1 Normal anterior sub-hepatic appendix incidentally found next to the gallbladder during laparoscopic cholecystectomy. 


\section{BMJ Case Reports}

\section{Learning points}

- Sub-hepatic appendix is a rare anatomic variation and it is usually in retrocaecal position.

- Sub-hepatic appendicitis mimic acute cholecystitis symptoms and should be suspected in young patients.

- Ultrasound scan examination could confuse subhepatic appendicitis with cholecystitis due to the anatomic position and the possible presence of fecalith.

- Laparoscopic procedure is the treatment of choice for such cases.

Competing interests None

Patient consent Obtained.

\section{REFERENCES}

1. Palanivelu C, Rangarajan M, John SJ, et al. Laparoscopic appendectomy for appendicitis in uncommon situations: the advantages of a tailored approach. Singapore Med J 2007; 48:737-40.

2. Patel NR, Lakshman S, Hays TV, et al. Subhepatic appendix with fecalith mimicking acute cholecystitis with gallstone. J Clin Ultrasound 1996;24:45-7.

This pdf has been created automatically from the final edited text and images.

Copyright 2010 BMJ Publishing Group. All rights reserved. For permission to reuse any of this content visit http://group.bmj.com/group/rights-licensing/permissions.

BMJ Case Report Fellows may re-use this article for personal use and teaching without any further permission.

Please cite this article as follows (you will need to access the article online to obtain the date of publication)

Isreb S, Holtham S. Incidental finding of an anterior sub-hepatic appendix during laparoscopic cholecystectomy. BMJ Case Reports 2010;

10.1136/bcr.04.2010.2883, date of publication

Become a Fellow of BMJ Case Reports today and you can:

- Submit as many cases as you like

Enjoy fast sympathetic peer review and rapid publication of accepted articles

Access all the published articles

- Re-use any of the published material for personal use and teaching without further permission

For information on Institutional Fellowships contact consortiasales@bmjgroup.com

Visit casereports.bmj.com for more articles like this and to become a Fellow 